\title{
HUBUNGAN PERILAKU HIDUP SEHAT DENGAN STATUS KESEHATAN MASYARAKAT KELURAHAN UJUNG
}

\author{
RELATIONSHIP BETWEEN HEALTHY BEHAVIOR AND HEALTH STATUS IN \\ KELURAHAN UJUNG
}

\author{
Sulistiarini, Rahmat Hargono \\ Departemen Promosi Kesehatan dan Ilmu Perilaku, \\ Fakultas Kesehatan Masyarakat Universitas Airlangga, Surabaya. \\ Email: Rinnisulis22@yahoo.co.id
}

\begin{abstract}
Health is a human right and one of elements of welfare that must be realized. Four main factors affecting health status are genetics, environment, behaviors, and health care facilities. Semampir District had poor health status. Poor health status caused by unhealthy behavior of the community. This research aimed to analyze the relation between healthy life behavior and health status of the community in RW XIII Kelurahan Ujung, Kecamatan Semampir, Surabaya. This research was a quantitative method by using Cross Sectional approach. Simple Random Sampling was used in sampling, there was 136 participants. Data collection used primary and secondary data. The independent variables in this research consisted of smoking behavior, exercises, fruits and vegetables consumption behavior. The dependent variable was health status. The collected data were analyzed using Chi-square analysis, to determine whether there was a significant relationship beetwen there search subjects. There was a relationship between vegetable consumption, fruit consumption and smoking behavior with health status by the $p$ value 0,009, 0,006 and 0,001 respectively as a result. Moreover exercises had no relation with health status byp value was about 0.243 .
\end{abstract}

Keywords: healthy life behavior, health status

\begin{abstract}
Abstrak: Kesehatan merupakan unsur kesejahteraan yang harus diwujudkan dan hak asasi bagi setiap manusia. Empat faktor utama yang mempengaruhi status kesehatan masyarakat yaitu genetik dari keluarga, lingkungan, perilaku individu, dan fasilitas pelayanan kesehatan. Status kesehatan di Kecamatan Semampir termasuk rendah. Status kesehatan rendah disebabkan perilaku tidak sehat dari masyarakat. Penelitian ini mempunyai tujuan mengetahui hubungan antara perilaku hidup sehat dengan status kesehatan masyarakat di RW XIII Kelurahan Ujung Kecamatan Semampir Surabaya. Penelitian ini bersifat kuantitatif dengan menggunakan pendekatan Cross Sectional. Teknik dalam penentuan sampel adalah Simple Random Sampling, sampel sebanyak 136 responden. Pengumpulan data dalam penelitian ini menggunakan data primer dan data sekunder. Variabel bebas dalam penelitian ini terdiri dari perilaku merokok, aktivitas fisik, perilaku mengonsumsi buah, dan perilaku mengonsumsi sayur. Variabel terikat dalam penelitian ini adalah status sehat. Data yang terkumpul dianalisis menggunakan analisis Chi-square dengan tujuan mengetahui kuat hubungan subjek penelitian. Hasil dari penelitian yaitu terdapat hubungan antara konsumsi sayur, konsumsi buah dan perilaku merokok dengan status kesehatan yaitu dengan hasil $\mathrm{p}$ value sebesar $0,009,0,006$ dan 0,001. Serta tidak terdapat hubungan antara olahraga dengan status kesehatan dengan hasil $\mathrm{p}$ value sebesar 0,243 .
\end{abstract}

Kata kunci: perilaku hidup sehat, status kesehatan

\section{PENDAHULUAN}

Kesehatan merupakan hal penting dalam kaitannya dengan produktivitas seseorang. Pada hakikatnya, setiap manusia membutuhkan kehidupan yang sehat untuk menunjang keberlangsungan hidupnya. Menurut Undang-Undang Republik Indonesia Nomor 36 tahun 2009 kesehatan merupakan keadaan sehat, baik secara fisik, mental, spiritual maupun sosial yang memungkinkan setiap orang untuk hidup produktif secara sosial maupun ekonomi. Kesehatan merupakan salah satu unsur kesejahteraan yang harus diwujudkan dan merupakan hak asasi bagi setiap manusia. Hal ini sesuai dengan cita-cita bangsa Indonesia sebagaimana dimaksud dalam Pancasila dan Undang-Undang Dasar Negara RI Tahun 1945. Berdasarkan pemaparan 
tersebut, dapat ditarik kesimpulan bahwa kesehatan itu bersifat holistik. Bukan hanya fisik melainkan jiwa dan sosial ekonomi.

Status kesehatan masyarakat merupakan salah satu faktor penting yang dapat berpengaruh terhadap kualitas sumber daya manusia dalam mendukung pembangunan di suatu negara. Negara akan berjalan secara optimal apabila penduduk memiliki status kesehatan masyarakat yang baik. Adanya peningkatan status kesehatan masyarakat tentu bukan hanya tugas dari institusi kesehatan, tetapi juga integrasi dari berbagai pihak dan tidak lepas dari dukungan masyarakat sendiri. Jadi, seorang manusia mempunyai tanggung jawab untuk menjaga status kesehatan pada dirinya. Karena sumbangsih individu akan mempengaruhi tinggi rendahnya status kesehatan masyarakat sebagai pondasi kesejahteraan.

Status kesehatan individu atau masyarakat merupakan hasil interaksi beberapa faktor dari dalam individu tersebut (internal) dan faktor luar (eksternal). Faktor internal meliputi faktor psikis dan fisik. Sedangkan faktor eksternal meliputi faktor budaya, ekonomi, politik, lingkungan fisik dan lain sebagainya. Salah satu teori yang menjelaskan tentang status kesehatan adalah teori dari HL. Blum. HL. Blum, dikutip Notoadmodjo (2012) dalam konsepnya menjelaskan bahwa terdapat empat faktor utama yang mempengaruhi status kesehatan seseorang atau suatu komunitas masyarakat. Beberapa faktor ini meliputi genetik dari keluarga, lingkungan sekitar seperti sosial masyarakat, ekonomi yang berkembang, politik dan budaya setempat, perilaku termasuk gaya hidup individu, dan fasilitas pelayanan kesehatan (jenis cakupan dan kualitas). Status kesehatan akan tercapai bila keempat faktor tersebut berada dalam kondisi yang optimal. Sedangkan, determinan yang paling besar mempengaruhi tinggi rendahnya status kesehatan adalah faktor lingkungan dan perilaku. Oleh karenanya, perlu diupayakan lingkungan yang sehat dan perilaku hidup sehat.

HL. Blum juga menyebutkan 12 indikator yang berhubungan dengan status atau derajat kesehatan yaitu (1) lamanya usia harapan untuk hidup masyarakat.(2) keadaan sakit atau cacat secara anatomis dan fisiologis. (3) keluhan sakit dari masyarakat tentang keadaan fisik, sosial dan juga kejiwaan pada dirinya. (4) ketidakmampuan seseorang untuk bersosialisasi dan melakukan pekerjaan dikarenakan sakit. (5) kemauan dan kemampuan masyarakat untuk berpartisipasi menjaga dirinya agar selalu dalam keadaan sehat. (6) perilaku individu secara langsung berkaitan dengan masalah kesehatan. (7) perilaku masyarakat terhadap lingkungan, dan ekosistem. (8) perilaku individu atau masyarakat terhadap sesamanya, keluarga dan komunitasnya. (9) kualitas komunikasi antar anggota masyarakat. (10) daya tahan individu atau masyarakat terhadap penyakit. (11) kepuasan masyarakat terhadap lingkungan sosialnya yang terdiri dari rumah, pekerjaan, sekolah, rekreasi, transportasi dan lain-lain. (12) kepuasan individu atau masyarakat terhadap seluruh aspek kehidupan dirinya sendiri.

Perilaku hidup sehat adalah salah satu peran penting dan berpengaruh positif terhadap terwujudnya status kesehatan masyarakat. Perilaku hidup sehat merupakan perilaku yang berkaitan dengan upaya atau usaha seseorang agar dapat mempertahankan dan meningkatkan derajat kesehatannya, Notoadmodjo (2007). Menurut Becker (1979) dalam Notoadmodjo (2007), mengklasifikasikan gaya hidup sehat yaitu olah raga teratur, tidak merokok, makan dengan menu seimbang, tidak mengonsumsi narkoba dan minuman keras, mengendalikan stres, istirahat cukup, dan berperilaku hidup positif bagi kesehatan. Menurut Depkes (2002) indikator gaya atau perilaku hidup sehat adalah perilaku tidak merokok, aktivitas fisik secara teratur dan pola makan seimbang.

Human Population Laboratory di California Departemen of Health menerbitkan daftar kebiasaan atau perilaku yang berkaitan dengan kesehatan yaitu olahraga atau aktivitas fisik secara teratur, tidur yang cukup, makan secara teratur, sarapan yang baik, mengendalikan berat badan, serta tidak mengonsumsi rokok, alkohol dan obat-obatan terlarang (Sharkey, 2003). Menurut kemendiknas dalam Suharjana (2012)pola hidup sehat terdiri dari mengonsumsi makanan dengan gizi 
seimbang, mengonsumsi makanan berserat tinggi, mengonsumsi buah dan sayur segar setiap hari, menghindari makanan yang mengandung tinggi lemak, gula dan garam, mengonsumsi susu atau produk lainnya dari susu setiap hari, selalu berfikir positif, menjaga berat badan dalam batas normal, olah raga teratur, cukup istirahat, minum air putih 1,5-2 liter perhari dan tidak merokok.

Penelitian yang dilakukan oleh Guang (2002) menyebutkan bahwa $80 \%$ penyakit kronis yang menyerang manusia disebabkan oleh perilaku hidup yang tidak sehat. Sedangkan $20 \%$ yang lain disebabkan oleh faktor lain. Menurut data WHO pada tahun 2008, 57 juta kematian terjadi di dunia dan $63 \%$ diantaranya atau sebesar 36 juta disebabkan oleh penyakit tidak menular yang disebabkan oleh gaya hidup tidak sehat. Sekitar 9 juta kematian akibat penyakit tidak menular terjadi pada usia $<60$ tahun. Kematian akibat penyakit tidak menular semakin meningkat. Peningkatan terbesar terjadi pada negara-negara menengah dan miskin termasuk Indonesia. Di Indonesia penyakit tidak menular mengalami peningkatan dari $41,7 \%$ menjadi $59,5 \%$. Pada tahun 2008 terdapat 481.700 perempuan dan 582.300 laki-laki meninggal karena penyakit tidak menular (Depkes RI, 2012). Oleh karena itu setiap individu jika ingin menjaga status kesehatannya, maka individu tersebut harus melakukan perilaku sehat dalam kesehariannya.

Data profil kesehatan Surabaya 2015 kondisi perilaku hidup bersih dan sehat di kecamatan Semampir tergolong yang rendah dibandingkan kecamatan lain di Surabaya. Rerata dari 3 wilayah kerja puskesmas di kecamatan Semampir hanya 55,26\% masyarakat yang melakukan perilaku hidup bersih dan sehat. Hal tersebut jauh dari rerata perilaku hidup bersih dan sehat Kota Surabaya. Masalah tersebut dapat menimbulkan munculnya berbagai macam penyakit yang berimbas pada turunnya status kesehatan masyarakat di Kecamatan Semampir.

Kecamatan Semampir merupakan salah satu kecamatan di Surabaya dengan peningkatan jumlah penduduk yang tinggi dan tingkat kemiskinan tertinggi di Kota
Surabaya. Selain itu, terjadi kenaikan angka kematian di Kecamatan Semampir dari tahun 2010-2012 (Fistianto dkk, 2015). Dengan jumlah penduduk yang tinggi, pemukiman tempat tinggal yang padat, sanitasi yang tidak baik, serta banyaknya penduduk yang miskin akan mempengaruhi status kesehatan masyarakat di Kecamatan Semampir. Dilihat dari Angka harapan hidup, dapat digolongkan dalam angka harapan hidup yang rendah karena hanya berkisar umur 60 tahun. Selain itu, angka kelahiran di Kecamatan Semampir naik dari tahun ke tahun. Kelurahan Ujung yang merupakan bagian dari kecamatan Semampir turut berkontribusi dalam status kesehatan masyarakat di Kecamatan Semampir.

Berdasarkan latar belakang diatas, maka perlu dilakukan penelitian mengenai hubungan antara perilaku hidup sehat terhadap status kesehatan masyarakat yang ada di RW XIII Kelurahan Ujung Kecamatan Semampir Surabaya. Tujuan dari penelitian ini adalah mengetahui hubungan antara perilaku hidup sehat yang terdiri dari perilaku merokok, kebiasaan makan buah dan sayur serta perilaku merokok dengan status dalam kesehatan. Variabel dependen atau terikat penelitian ini adalah status kesehatan yang dinilai adalah adanya angka kesakitan dalam satu sampai enam bulan terakhir. Variabel independen atau bebas dalam penelitian ini adalah perilaku hidup sehat yang terdiri dari perilaku merokok, aktivitas fisik, konsumsi buah dan konsumsi sayur.

\section{METODE}

Penelitian ini bersifat kuantitatif untuk menganalisis hubungan antara status kesehatan dengan perilaku sehat. Jenis penelitian ini termasuk kedalam Cross Sectional karena hanya dilakukan pada satu waktu. Penelitian ini dilakukan di RW XIII Kelurahan Ujung Kecamatan Semampir Surabaya pada bulan Januari 2017. Populasi dalam penelitian adalah 35.000 Orang dengan 1242 Kepala Keluarga (KK). Pengambilan sampel menggunakan metode Simple Random Sampling. Setelah dilakukan perhitungan diperoleh sampel sebanyak 136 responden. 
Variabel bebas dalam penelitian ini adalah perilaku hidup sehat. Perilaku tersebut terdiri dari perilaku merokok, aktivitas fisik atau olah raga, perilaku mengonsumsi buah dan perilaku mengonsumsi sayur. Variabel tersebut diadopsi dari indikator perilaku hidup sehat Depkes (2002) yaitu perilaku tidak merokok, aktivitas fisik secara teratur dan pola makan seimbang. Variabel terikat dalam penelitian ini adalah status kesehatan.

Pengumpulan data dalam penelitian ini menggunakan data primer dan data sekunder. Data primer didapatkan dengan wawancara menggunakan instrumen kuesioner yang meliputi perilaku merokok yang dinilai berdasarkan kebiasaan merokok, kebiasaan makan buah dan sayur yang dinilai berdasarkan porsi makan sayur dan buah dalam sehari serta aktivitas fisik yang dinilai berdasarkan olah raga rutin dalam satu minggu. Data sekunder didapatkan dari data RW XIII kelurahan Ujung, balai kelurahan Ujung, jurnal ilmiah, buku, artikel dan sebagainya.

Batasan operasional variabel terikat dalam penelitian ini adalah dinilai dengan menyatakan keluhan sakit atau kesakitan yang dirasakan masyarakat dalam 1 sampai 6 bulan terakhir. Penilaian status kesehatan ini diambil dari salah satu indikator status kesehatan menururt HL. Blum yaitu keadaan sakit secara anatomis maupun fisiologis. Status kesehatan baik apabila responden tidak ada keluhan sakit atau kesakitan yang dirasakan selama 1 sampai 6 bulan terakhir. Apabila responden mempunyai salah satu keluhan kesehatan dalam waktu 1 sampai 6 bulan terakhir maka dikatakan status kesehatan tidak baik (Hapsari, dkk 2006). Sedangkan untuk variabel bebas yaitu perilaku merokok yaitu kebiasaan merokok responden setiap harinya. Konsumsi buah dan sayur yaitu jumlah porsi konsumsi buah dan sayur dalam sehari. Aktivitas fisik yaitu frekuensi olah raga yang dilakukan setiap minggunya.

Data yang terkumpul selanjutnya dilakukan klasifikasi ulang data, pemberian kode untuk tiap kelompok dan memasukkan data. Data yang telah dimasukkan dilakukan analisis dengan menggunakan analisis deskriptif dengan tujuan untuk mengetahui gambaran dan distribusi frekuensi karakteristik setiap variabel yang diteliti. Analisis berikutnya menggunakan analisis Chi-square digunakan untuk melihat kuat hubungan antar variabel bebas dengan variabel terikat. Tiap variabel bebas satu persatu dianalisis untuk mengetahui seberapa kuat hubungan dengan variabel terikat. Nilai uji signifikansi pada penelitian dengan $\alpha$ sebesar 5\%. Hipotesis diterima jika $\alpha \leq$ $5 \%$, Hipotesis ditolak jika nilai $\alpha \geq 5 \%$.

\section{HASIL DAN PEMBAHASAN}

Pada penelitian yang telah dilakukan, diambil hasil karakteristik responden berdasarkan umur dan pendidikan. Karakteristik responden dapat dilihat pada tabel 1 di bawah ini:

Berdasarkan tabel 1, penduduk yang berusia 20-35 tahun sebanyak 84 responden atau $61,8 \%$ dan dari 136 responden hanya terdapat satu responden yang berusia 66-75 tahun. Hal ini menunjukkan bahwa RW XIII Kelurahan Ujung memiliki banyak usia produktif.

Tabel 1. Karakteristik responden berdasarkan umur dan pendidikan

\begin{tabular}{|c|c|c|}
\hline Karakteristik & Frekuensi & $\%$ \\
\hline \multicolumn{3}{|l|}{ Umur } \\
\hline $20-35$ & 84 & 61,8 \\
\hline $36-45$ & 35 & 25,7 \\
\hline $46-65$ & 16 & 11,8 \\
\hline $66-75$ & 1 & 0,7 \\
\hline Total & 136 & 100 \\
\hline \multicolumn{3}{|l|}{ Pendidikan } \\
\hline Tidak Sekolah & 19 & 14,0 \\
\hline Tidak Lulus SD & 4 & 2,90 \\
\hline $\mathrm{SD} /$ Sederajat & 57 & 41,9 \\
\hline SMP/Sederajat & 34 & 25,0 \\
\hline SMA/Sederajat & 19 & 14,0 \\
\hline PT & 3 & 2,20 \\
\hline Total & 136 & 100 \\
\hline
\end{tabular}

Berdasarkan tingkat pendidikan, mayoritas responden berpendidikan SD yaitu sebesar $41,9 \%$, sementara hanya 3 $(2,20 \%)$ orang responden dengan pendidikan tinggi. Hal ini menunjukkan bahwa banyak masyarakat di RW XIII kelurahan Ujung banyak yang berpendidikan rendah. 
Analisis terhadap data primer dari 136 sampel di RW XIII Kelurahan Ujung, ditunjukkan bahwa banyak dari penduduk Kelurahan Ujung berusia produktif. Kelompok masyarakat dengan umur yang didominasi oleh usia produktif akan menjadi nilai tambah yang baik bagi RW XIII Kelurahan Ujung. Banyaknya usia produktif diharapkan dapat meningkatkan status ekonomi masyarakat serta menjadi SDM yang berkualitas untuk kemajuan bangsa khususnya di RW XIII Kelurahan Ujung yang diharapkan akan berdampak terhadap peningkatan status kesehatan masyarakat itu sendiri.

Dari karakteristik pendidikan responden di RW XIII Kelurahan Ujung sebagian besar responden menunjukkan tingkat pendidikan yang rendah. Pendidikan juga dapat menjadi penentu karakteristik suatu masyarakat karena tingkat pendidikan yang rendah akan membuat masyarakat atau seseorang sulit untuk menerima informasi perilaku sehat baik dari media massa ataupun orang lain. Hal ini berdampak pada cara pandang responden terhadap pentingnya status kesehatan karena, semakin tinggi pendidikan seseorang maka akan semakin mudah seseorang untuk menerima dan mengerti informasi yang disampaikan khususnya informasi kesehatan.

Kelurahan Ujung memiliki potensi yang besar dengan banyaknya usia produktif yang ada di dalamnya. Pendidikan yang kurang dari sebagian besar penduduknya menjadi penghalang dari potensi tersebut, karena akan membuat kurangnya informasi kesehatan yang didapatkan. Akibatnya berdampak pada status kesehatan secara umum di RW XIII Kelurahan Ujung.

Status kesehatan pada 136 responden yang telah diteliti mendapatkan hasil lebih dari separuh responden memiliki status kesehatan yang tidak baik. Hasil penelitian melalui wawancara pada tabel 2 :

Tabel 2. Gambaran status kesehatan

\begin{tabular}{|c|c|c|}
\hline Status Kesehatan & Frekuensi & $(\%)$ \\
\hline Baik & 58 & 42,8 \\
\hline Tidak Baik & 78 & 57,4 \\
\hline Total & 136 & 100 \\
\hline
\end{tabular}

Dari tabel 2, menunjukkan sebanyak $57,4 \%$ atau sebanyak 78 responden status kesehatannya dalam kondisi tidak baik. Dari batasan operasional penelitian, hal tersebut diartikan bahwa lebih dari 50\% responden mengalami keluhan kesakitan dalam waktu 1 sampai 6 bulan terakhir. Sedangkan $42,8 \%$ responden tidak mengalami keluhan kesakitan. Hal ini menunjukkan bahwa sebagian besar masyarakat RW XIII kelurahan Ujung memiliki kondisi kesehatan yang tidak baik. Buruknya status kesehatan masyarakat tentu akan menimbulkan dampak bagi masyarakat itu sendiri, seperti akan mengganggu aktivitas sehari-hari hingga akan menurunkan produktivitas.

Dari hasil survey yang dilakukan, banyak faktor yang mempengaruhi status kesehatan masyarakat RW XIII kelurahan Ujung memiliki kondisi kesehatan yang tidak baik, diantaranya karena lingkungan tempat tinggal yang terlalu padat, sanitasi yang kurang baik, serta perilaku masyarakat itu sendiri.

Status kesehatan masyarakat dapat dihubungkan oleh berbagai faktor. Salah satu faktor yang berhubungan adalah perilaku sehat dari masyarakatnya. Semakin masyarakat berperilaku sehat, maka status kesehatan masyarakat akan baik. Hal ini sesuai dengan penelitian Hapsari, dkk (2009) yang memberikan kesimpulan bahwa salah satu faktor yang berhubungan dengan status kesehatan masyarakat adalah perilaku sehat. Perilaku sehat pada tiap responden sangat berperan terhadap baik tidaknya status kesehatan yang dimiliki.

Gambaran Perilaku sehat yang digunakan dalam penelitian ini terdiri dari:

Gambaran perilaku merokok responden dapat dilihat pada tabel 3 .

Tabel 3. Berdasarkan tingkat pendidikan

\begin{tabular}{lll}
\hline Kebiasaan Merokok & Frekuensi & \multicolumn{1}{c}{$(\mathbf{\%})$} \\
Merokok & 101 & 74,3 \\
Tidak Merokok & 25 & 25,7 \\
\hline Total & 136 & 100 \\
\hline
\end{tabular}

Bedasarkan tabel 3, sebagian besar masyarakat RW XIII kelurahan Ujung adalah perokok aktif dan berpotensi terserang penyakit degeneratif dan penyakit infeksi yang akan mengganggu status kesehatan. 
Perilaku merokok dalam penelitian ini terbagi menjadi dua kelompok yaitu, kelompok yang memiliki kebiasaan merokok dan tidak memiliki kebiasaan merokok. Dari hasil analisis didapatkan bahwa mayoritas responden merokok. Perilaku merokok merupakan salah satu perilaku hidup yang tidak sehat. Hal ini dibuktikan dengan kejadian kesakitan yang disebabkan oleh rokok. Kasus kanker paru sebagian besar diakibatkan oleh rokok yaitu sekitar90\% dan sekitar 80\% kasus kanker esofagus telah dikaitkan dengan merokok. Selain itu, Penyakit jantung koroner dan lainnya merupakan akibat dari merokok (Bararah, 2011). Tidak hanya merugikan perokok aktif, kesehatan perokok pasif pun terancam dengan adanya perokok aktif yang ada di lingkungan sekitar mereka. Hal ini dikarenakan asap rokok yang terhirup oleh perokok pasif mengandung racun dan bahan kimia termasuk nikotin sebagaimana yang dialami oleh perokok.

Berdasarkan hasil wawancara terhadap 136 responden diperoleh data kebiasaan makan sayur dan buah sebagai berikut:

Tabel 4. Gambaran kebiasaan makan buah dan sayur

\begin{tabular}{ccc}
\hline Kebiasaan Makan Sayur & Frekuensi & $\mathbf{( \% )}$ \\
\hline 0 porsi & 40 & 29,4 \\
1 porsi & 72 & 52,9 \\
2 porsi & 24 & 17,6 \\
\hline Total & 136 & 100 \\
\hline Kebiasaan Makan Buah & & \\
\hline 0 porsi & 26 & 19,1 \\
1 porsi & 95 & 69,9 \\
2 porsi & 15 & 11,0 \\
\hline Total & 136 & 100 \\
\hline
\end{tabular}

Konsumsi sayur dalam penelitian ini dikelompokkan berdasarkan porsi kebiasaan makan sayur perharinya yang terdiri dari kelompok tidak makan sayur setiap hari, satu porsi sayur setiap hari dan 2 porsi sayur setiap hari. Sama halnya dengan kebiasaan makan sayur, kebiasaan maka buah dikelompokkan menjadi tidak makan buah dalam setiap hari, satu buah sayur setiap hari dan 2 porsi buah setiap hari. Berdasarkan tabel 4,responden paling banyak mengonsumsi buah dan sayur 1 porsi perhari yaitu sebesar $52,9 \%$ untuk sayur dan
$69,9 \%$ untuk buah. Hal ini menunjukkan bahwa sebagian besar masyarakat di RW XIII Kelurahan Ujung masuk dalam kategori kurang mengonsumsi buah dan sayur menurut Riskesdas (2013). Kurang mengonsumsi sayur dan buah akan lebih mudah terkena penyakit sehingga akan mengganggu status kesehatan.

Penduduk atau masyarakat dikategorikan 'cukup' mengonsumsi buah dan/atau sayur apabila makan buah dan/ atau sayur minimal 5 porsi/hari selama 7 hari dalam seminggu. Dikategorikan 'kurang' apabila konsumsi sayur dan/ atau buah kurang dari ketentuan tersebut (Riskedas, 2013). Berdasarkan data tersebut maka seluruh responden masuk dalam kategori kurang untuk konsumsi buah dan sayur dikarenakan tidak ada responden yang mengonsumsi sayur dan/atau buah 5 porsi perhari. Dari hasil analisis lanjut ini didapatkan bahwa, konsumsi buah dan sayur masyarakat Indonesia masih tergolong rendah yaitu sebesar97,1\%pada semua kelompok umur bila dibandingkan dengan anjuran konsumsi buah dan sayur dalam pedoman gizi seimbang 2014.

Menurunnya tingkat konsumsi buah dan sayur menyebabkan perubahan pola penyakit infeksi menjadi penyakit metabolik dan degeneratif. Serat pangan pada buah dan sayur juga menguntungkan bagi kesehatan yaitu berfungsi mengontrol berat badan, menanggulangi penyakit diabetes, mengurangi tingkat kolesterol darah dan penyakit kardiovaskuler serta mencegah gangguan gastrointestinal, kanker kolon (Santoso, 2011).

Menurut Santoso (2011), salah satu faktor yang menyebabkan penurunan konsumsi buah dan sayur pada masyarakat perkotaan adalah tingkat mobilitas tinggi dan cenderung mengonsumsi makanan siap saji sehingga terjadi pergeseran pola makan dari tinggi karbohidrat, tinggi serat, dan rendah lemak ke pola konsumsi rendah karbohidrat dan serat, tinggi lemak dan protein. Menurut hasil penelitian Khuril'in (2015) status sosial ekonomi berpengaruh terhadap konsumsi ikan, sayur, dan buah dikarenakan pendapatan dan pekerjaan memang berpengaruh besar terhadap konsumsi pangan masyarakat. Semakin 
tinggi status sosial masyarakat, semakin tinggi pula konsumsi pangan masyarakat tersebut.

Gambaran aktivitas fisik dari 136 responden adalah sebagai berikut: Aktivitas fisik dalam penelitian ini adalah frekuensi melakukan olah raga dalam seminggu yang dikelompokkan menjadi tidak pernah, sekali seminggu, dua kali seminggu dan tiga kali dalam seminggu. Berdasarkan tabel 5 hampir seluruh responden yaitu sebesar $97,1 \%$ tidak pernah berolah raga dalam seminggu. Terdapat 4 responden yang rutin melakukan olahraga rutin setiap minggunya yang terdiri dari 1 kali seminggu 1 responden. 2 kali seminggu 2 responden dan 3 kali seminggu 1 responden. Hampir seluruh masyarakat RW XIII Kelurahan Ujung tidak pernah melakukan olah raga. Banyaknya responden yang tidak melakukan aktivitas fisik berupa olah raga menunjukkan tingkat kesadaran berolah raga dari masyarakat Kelurahan Ujung yang sangat rendah.

Tabel 5. Gambaran Aktivitas Fisik

\begin{tabular}{ccc}
\hline Kebiasaan Olah Raga & Frekuensi & $\mathbf{( \% )}$ \\
\hline Tidak pernah & 132 & 97,1 \\
1 kali & 1 & 0,7 \\
2 kali & 2 & 1,5 \\
3 kali & 1 & 0,7 \\
\hline Total & 136 & 100 \\
\hline
\end{tabular}

Menurut Rikesdas (2013) aktivitas fisik secara teratur dapat bermanfaat untuk menguatkan sistem jantung dan pembuluh darah serta dapat mengatur berat badan. Berolah raga selama minimal 10 menit dilakukan minimal tiga hari dalam seminggu masuk dalam aktivitas fisik berat.

Sekitar dua juta orang di seluruh dunia meninggal karena penyakit akibat kurang berolahraga dan gaya hidup malas. Menurut penelitian University of Hong Kong dalam prasetyo 2014 dampak jangka panjang dari tidak pernah melakukan olahraga sama berbahaya dengan dampak merokok dan sekitar $20 \%$ penyebab kematian orang dengan usia $>35$ tahun adalah kurang olah raga.

Setelah diketahui distribusi frekuensi selanjutnya dilakukan uji Chi-square. Hasil uji Chi-square antara variabel bebas (kebiasaan makan sayur dan buah, perilaku merokok dan aktivitas fisik) dengan variabel terikat (status kesehatan) adalah sebagai berikut:

Tabel 6 menunjukkan bahwa terdapat hubungan antara konsumsi sayur terhadap status kesehatan serta adanya hubungan antara konsumsi buah dengan status kesehatan. Namun hubungan bersifat lemah dikarenakan hasil dari koefisien kontingensinya sebesar 0,255 dan 0,266. Hal ini berarti masyarakat yang cukup mengonsumsi buah dan sayur akan meningkatkan status kesehatan.

Tabel 6. Hubungan Status Kesehatan dengan Perilaku Sehat

\begin{tabular}{lcc}
\hline & $\begin{array}{c}\text { Koefisien } \\
\text { Kontingensi }\end{array}$ & P Value \\
\hline $\begin{array}{l}\text { Hubungan } \\
\text { mengonsumsi } \\
\text { sayur dengan status } \\
\text { kesehatan }\end{array}$ & 0,255 & 0,009 \\
\hline $\begin{array}{l}\text { Hubungan } \\
\text { mengonsumsi } \\
\text { buah dengan status } \\
\text { kesehatan }\end{array}$ & 0,266 & 0,006 \\
\hline $\begin{array}{l}\text { Hubungan perilaku } \\
\text { merokok status } \\
\text { kesehatan dengan }\end{array}$ & 0,295 & 0,001 \\
\hline $\begin{array}{l}\text { Hubungan olah } \\
\text { raga dengan status } \\
\text { kesehatan olah raga }\end{array}$ & 0,173 & 0,243 \\
\hline
\end{tabular}

Sesuai dengan penelitian yang dilakukan Astian (2016) yaitu terdapat hubungan antara konsumsi sayur dan buah terhadap status gizi pada remaja dengan $p$ value 0,000 . Semakin beragam jenis makanan yang dikonsumsi, maka semakin banyak antioksi dan baik nutrient maupun non nutrient yang dihasilkan. Antioksidan alami dapat diperoleh dari berbagai jenis sayur dan buah seperti brokoli, kubis, sawi hijau, jeruk dan lain sebagainya. Selain itu, sayur dan buah juga mengandung zat besi dan vitamin yang sangat baik untuk tubuh dan masih banyak kandungan yang lainnya di dalam sayuran yang baik untuk kesehatan. Oleh sebab sayur dan buah penting untuk kesehatan tubuh, maka hendaknya konsumsi sayur setiap hari sesuai anjuran yang telah ditetapkan. Namun, 
sebaliknya apabila kurang mengonsumsi sayur, dapat menyebabkan berbagai keadaan yang mengganggu kesehatan seperti anemia, kekurangan vitamin dan lain sebagainya.

Horne (2010), kurang mengonsumsi sayur dan buah juga erat kaitannya dengan obesitas. Horne juga menambahkan bahwa dengan rajin mengonsumsi buah setiap kali waktu makan maka akan menghindari terjadinya kenaikan berat badan. Menurut Sunita (2006) Konsumsi sayur dan buah sangat penting dalam kehidupan seharihari karena mengandung zat gizi seperti vitamin dan mineral, sumber serat makanan, memiliki kadar air tinggi, antioksidan dan berfungsi sebagai zat pengatur, serta dapat mencegah terjadinya berbagai penyakit degenerative seperti diabetes, obesitas, hipertensi penyakit jantung coroner, dan kanker.

Menurut Mak (2012), kekurangan konsumsi sayur dan buah dapat menimbulkan berbagai penyakit di kemudian hari. Rendahnya mengonsumsi sayur dan buah dapat meningkatnya risiko terjadinya penyakit kronik diantaranya hipertensi, penyakit jantung dan diabetes. Anak yang mengonsumsi sayur dan buah dalam jumlah yang cukup tinggi pada masa kanak-kanaknya mempunyai kesehatan yang lebih baik dan dapat mengurangi risiko terkena penyakit kronik yang berkaitan dengan diet.

Berlainan dengan penelitian yang dilakukan oleh Rahayuningtyas tahun 2012, menyatakan bahwa tidak ada hubungan bermakna antara asupan serat pada sayur dengan status gizi. Ada beberapa hal yang dapat mendasari peristiwa ini seperti pendidikan masyarakat, sosial ekonomi keluarga, dan infeksi pangan. Makaryani (2013) menjelaskan, konsumsi serat yang rendah dapat mengakibatkan terjadi gizi lebih dan meningkatnya penyakit degeneratif.

Dari tabel 6 perilaku merokok dengan status kesehatan menunjukkan hasil dengan nilai signifikan $p$ Value $=0.001(\mathrm{sig}<0,05)$ yang berarti terdapat hubungan antara perilaku merokok dengan status kesehatan. Dilihat dari kuat hubungan dengan status kesehatan, perilaku merokok menunjukkan hasil 0,295 yang berarti hubungan bersifat lemah. Hal ini berarti orang yang merokok berpotensi untuk terkena suatu penyakit yang akan mengganggu status kesehatan.

Merokok adalah salah satu kebiasaan yang mudah ditemui dalam kehidupan sehari-hari. Life style atau gaya hidup ini dianggap suatu hal yang menarik sebagai sebuah masalah dalam kesehatan, karena dianggap sebagai faktor risiko dari suatu penyakit degeneratif. Hasil penelitian menunjukkan bahwa hampir tidak ada perokok berat yang memulai merokok pada saat usia dewasa namun mereka telah memulai kebiasaan merokok sejak berusia belasan tahun (Bustan, 2000).

Kebiasaan merokok tidak dapat dihindari dari kehidupan masyarakat terutama para lelaki. Hal ini sesuai dengan penelitian Rochman tahun 2013 bahwa terdapat hubungan kebiasaan merokok dengan status gizi. Merokok dapat menyebabkan gingiva karena kandungan nikotin pada rokok yang membuat seseorang menjadi ketagihan sehingga ada keinginan untuk menambah jumlah batang rokok yang dihisap setiap hari. Selain itu, merokok juga dapat menyebabkan penyakit jantung. Penelitian yang dilakukan di Aceh tentang status kesehatan remaja dengan perilaku hidup sehat, menunjukkan bahwa sebesar $38 \%$ remaja status kesehatannya kurang baik. Salah satu perilaku tidak sehat yang diteliti adalah perilaku merokok dan mempunyai hubungan dengan status kesehatan. Mantan perokok mempunyai risiko 1,8 kali dibandingkan dengan yang tidak merokok (Puti, 2008)

Hal ini sesuai dengan teori yang menyatakan bahwa merokok dapat menyempitkan pembuluh darah di dalam jantung, mengurangi nafsu makan, serta mengganggu saluran pencernaan yang akan mengakibatkan proses penyerapan dalam tubuh terganggu (Arisman, 2009). Berkurangnya nafsu makan dan terganggunya proses penyerapan zat gizi dapat mengakibatkan gangguan gizi pada tubuh seseorang seperti Kekurangan Energi Protein (KEP). Individu yang merokok berisiko menjadi 2 kali lebih besar menjadi lebih kurus dibanding yang tidak merokok (Permaisih, 2004). Dengan demikian perlu upaya untuk meminimalkan 
kebiasaan merokok sehingga seluruh lapisan masyarakat dapat memperoleh kesehatan yang utuh dan menyeluruh.

Aktivitas fisik dengan status kesehatan menunjukkan hasil $\mathrm{p}$ Value 0,243 yang berarti tidak ada hubungan antara aktivitas fisik dengan status kesehatan. Hal ini dikarenakan hampir seluruh sampel tidak pernah melakukan olah raga sehingga frekuensi harapan tidak memenuhi syarat dalam perhitungan menggunakan rumus Chi-square. Dengan demikian tidak terdapat hubungan yang bermakna antara olah raga dengan status kesehatan. Hal ini berarti aktivitas fisik tidak berpengaruh terhadap status kesehatan.

Namun hasil dari Penelitian ini senada dengan penelitian Rochman (2013) bahwa tidak terdapat keterkaitan antara kebiasaan olahraga dengan status gizi. Aktivitas fisik dapat dilakukan di mana saja, tidak membutuhkan biaya yang mahal seperti jogging, bersepeda. Tidak hanya kebiasaan olah raga yang dapat mempengaruhi status gizi tetapi banyak faktor determinannya, antara lain penyakit infeksi, genetik, dan hormonal. Hasil penelitian Nurlika (2011) dalam jurnalnya mengenai hubungan antara pola konsumsi dan aktivitas fisik dengan status gizi pada lansia di panti dengan diperoleh hasil $\mathrm{RP}=1,005$, Confident Interval $0,638<\mathrm{RP}<1,585$ yang mencakup angka satu dengan $\mathrm{P}$ value $=0,981$. Halini menunjukkan tidak ada hubungan antara aktivitas fisik dengan status gizi. Hasil RP $=1,005$ menunjukkan bahwa seseorang yang tidak berolahraga memiliki 1,005 kali peluang untuk mengalami status gizi yang tidak baik dari pada seseorang yang berolahraga.

Berlainan dengan penelitian yang dilakukan oleh Anggraini (2014) yaitu terdapat hubungan yang bermakna antara tingkat aktivitas fisik dengan IMT ( $p=<$ 0,001 ) dengan kesimpulan seseorang yang melakukan aktivitas fisik yang cukup akan meningkatkan status gizi. Aktivitas fisik yang dilakukan secara reguler dapat dihubungkan dengan peningkatan penyerapan oksigen yang maksimal. Penurunan denyut jantung dan tekanan darah secara teratur dikaitkan dengan peningkatan penyerapan oksigen yang maksimal, penurunan persentase lemak tubuh, penurunan denyut jantung, tekanan darah dan meningkatkan perasaan akan kesehatan. Landers (1998) menambahkan bahwa aktivitas fisik secara teratur akan meningkatkan kualitas tidur dan kemampuan untuk mengatasi stres. Rendahnya aktivitas fisik secara teratur dapat menimbulkan masalah kesehatan, karena tubuh tidak maksimal dalam melakukan metabolisme sehingga orang dengan aktivitas rendah lebih mungkin menderita masalah terkait dengan obesitas, insiden kardiovaskuler dan beberapa jenis kanker.

\section{SIMPULAN}

Berdasarkan hasil penelitian yang telah dilakukan di RW XIII Kelurahan Ujung Kecamatan Semampir Surabaya, maka peneliti dapat menarik kesimpulan sebagai berikut: terdapat hubungan antara konsumsi sayur dengan status kesehatan serta adanya hubungan antara konsumsi buah dengan status kesehatan dengan, namun hubungan bersifat lemah. Terdapat hubungan yang signifikan antara perilaku merokok dengan status kesehatan dengan, namun hubungan bersifat lemah dan tidak terdapat hubungan antara olahraga dengan status kesehatan. Dengan demikian dapat disarankan untuk masyarakat Kelurahan Ujung agar merutinkan konsumsi sayur dan buah setiap harinya, mengurangi konsumsi rokok agar tidak memicu penyakit muncul. Saran bagi instalasi kesehatan lebih meningkatkan promosi kesehatan mengenai pentingnya makan sayur dan buah yang sesuai dengan wilayah dan budaya agar masyarakat dapat menerima dan mau mengonsumsi sayur dan buah secara rutin, serta meningkatkan promosi kesehatan tentang bahaya merokok untuk kesehatan.

\section{DAFTAR PUSTAKA}

Adliyani, Zaraz. 2015. Pengaruh Perilaku Indvidu terhadap Hidup Sehat. [e-journal] Lampung: Tersedia di http://jukeunila. com/diakses tanggal 5 April 2017).

Anggraini, Lonia. 2014. Hubungan Tingkat Aktivitas Fisik dengan Status Gizi pada Anak Usia Prasekolah.[e-journal] Semarang: Tersedia di http://eprints. 
undip.ac.id [diakses tanggal 1 mei 2017].

Arisman, 2009. Gizi dalam Daur Kehidupan. Jakarta: EGC.

Astian, Akbar. 2016. Hubungan Kebiasaan Sarapan dan Konsumsi Sayur Buah dengan Status Gizi Remaja. [e-journal] Makasar: Tersedia di http://repository. unhas.ac. [diakses tanggal 30 April 2017].

Bararah, Vera. 2011. Penyakit Akibat Rokok. Tersedia di https://health.detik.com/rea d/2011/07/07/174913/1676916/763/15penyakit-akibat-rokok [2 April 2017].

Blum HL. 1974. Planning for Health, development and aplication of social changes theory. New York: Human Sciences Press.

BPPK, RI. 2013. Riset Kesehatan Dasar. Jakarta.

BPPK, RI. 2010. Riset Kesehatan Dasar. Jakarta.

Bustan, M.N. 2000. Epidemiologi Penyakit tidak Menular. Rineka Cipta: Jakarta.

Departemen Kesehatan RI. 2002. Pedoman Pemberantasan Penyakit Saluran Pernafasan Akut. Jakarta: Departemen Kesehatan RI.

Departemen Kesehatan RI. 2012. Penyakit tidak Menular. Jakarta: Tersedia di www.depkes.go.id/download. php?file=download/pusdatin/buletin/ buletin-ptm.pdf. [20 April 2017]

Dinas Kesehatan Kota Surabaya. 2016. Profil Kesehatan Surabaya Tahun 2015. Surabaya: Dinkes Kota Surabaya.

Fistianto, Valdi. Dkk, 2015. Profil Kependudukan Kecamatan Semampir. Surabaya: ITS.

Guang, H.Z. 2002. "Gaya Hidup Usia Pertengahan dan Usia Lanjut Serta Pengaruhnya Terhadap Kesehatan". Makalah. (diterjemahkan oleh Suryono Limputra).

Hapsari, Dwi dkk. 2009. Pengaruh Lingkungan Sehat, dan Perilaku Hidup Sehat terhadap Status Kesehatan. [e-journal] Jakarta: Pusat penelitian dan pengembangan Ekologi dan Status Kesehatan. Tersedia di www.ejournal. litbang.depkes.go.id/diakses tanggal5 April 2017].
Horne, Pauline J, et al. 2010. Increasing Preschool Children's Consumption of Fruit and Vegetable, a Modeling amd Rewards Intervention. Appetite.

Khuril'in, Mei. 2015. Faktor-Faktor yang Berhubungan dengan Konsumsi Ikan, Sayur, dan Buah pada Anak Usia Prasekolah di TK LPII, Desa Sawotratap, Kecamatan Gendangan, Kabupaten Sidoarjo.. [e-journal] Surabaya: Tersedia di jurnal mahasiswa.unesa.ac.id/index. php/jurnal-tata-boga/article/view/1180 [diakses tanggal5 April 2017).

Landers D.M. \& Craft L. 1998. The effects of exercise on clinical depression resulting from mental illness: a meta analysis. $J$ Sport Exerc Psychol 20.

Mak, Tsz Ning, et al. 2012. Assessing Eating Context and Fruit and Vegetable Consumption in Children: New Methods Using Food Diaries in the UK National Diet and Nutrition Survey Rolling Programme. International Journal of Behavioural Nutrition and Physical Activity.

Makaryani. 2013. Hubungan Konsumsi Serat dengan Kejadian Overweight pada Remaja Putri SMA Batik 1 Surakarta. Skripsi. Universitas Muhamadiyah Surakarta.

Pradono, Julianty. 2013. Hubungan Antara Tingkat Pendidikan, Pengetahuan Tentang Kesehatan Lingkungan, Perilaku Hidup Sehat dengan Status Kesehatan. Tersedia di www.download.portalgaruda. org/article[5 April 2017].

Puti, Sari. 2008. Status Kesehatan Masyarakat dan Faktor-Faktor yang Berhubungan di Nanggroe Aceh Darussalam. Media Litbang Indonesia, Januari: Jakarta.

Notoatmodjo, Soekidjo. 2007. Promosi Kesehatan dan Ilmu Perilaku. Jakarta: Rineka Cipta.

Notoatmodjo, Soekidjo. 2012. Promosi Kesehatan dan Perilaku Kesehatan. Jakarta: Rineka Cipta.

Nurika, Ismayanti. 2011. Hubungan Antara Pola Konsumsi dan Aktivitas Fisik dengan Status Gizi Pada Lansia di Panti Sosial Tresna Werdha Unit Abiyoso Yogykarta. [e-journal] Yogyakarta.: Tersedia di www.journal.uad.ac.id [diakses tanggal 1 Mei 2017). 
Permaisih. 2004. Status Gizi Remaja dan Faktor-faktor yang Mempengaruhinya. Bandung: ITB.

Prasetyo, Yudik. Olahraga Bagi Orang yang Sibuk di Kantor. Yogyakarta: Tersedia di http://download.portalgaruda.org [5 April 2017].

Rahayuningtyas, 2013. Hubungan Antara Asupan Serat dan Faktor Lainnya dengan Status Gizi Lebih pada Siswa SMPN 115 Jakarta Selatan Tahun 2012. Skripsi. Universitas Indonesia Jakarta.

Rochman, Iftita. 2013. Hubungan Gaya Hidup dengan Status Gizi Remaja. Skripsi. Universitas Airlangga Surabaya.

Santoso, A. 2011. Serat Pangan (Dietary Fiber) dan Manfaatnya Bagi Kesehatan. [e-journal] Solo: Tersedia di http:// journals.ums.ac.id/[diakses tanggal 10 Aprl 2017].

Sharkey, B.J. 2003. Fitness and Health. Kebugaran dan Kesehatan (terjemahan Eri Desmarini Nasution). Jakarta: Raja Grafindo Persada.

Suharjana. 2012. Kebiasaan Berperilaku Hidup Sehat dan Nilai-nilai Pendidikan. [e-journal] Yogyakarta:

Tersedia di www.journal.uny.ac.id/index. php/jpka/article/view/1303/1084[diakses tanggal 30 April 2017]

Sunita A. 2006.PrinsipDasarIlmuGizi. Jakarta: Gramedia Pustaka Utama. 